"MSME lending and bank efficiency: Evidence from Indonesia"

\begin{tabular}{|c|c|}
\hline AUTHORS & $\begin{array}{l}\text { Irfan Adhityo Dinutistomo (iD) } \\
\text { Arief Wibisono Lubis (iD) }\end{array}$ \\
\hline ARTICLE INFO & $\begin{array}{l}\text { Irfan Adhityo Dinutistomo and Arief Wibisono Lubis (2021). MSME lending and } \\
\text { bank efficiency: Evidence from Indonesia. Banks and Bank Systems, 16(3), 93- } \\
\text { 103. doi:10.21511/bbs.16(3).2021.09 }\end{array}$ \\
\hline DOI & http://dx.doi.org/10.21511/bbs.16(3).2021.09 \\
\hline RELEASED ON & Wednesday, 15 September 2021 \\
\hline RECEIVED ON & Monday, 31 May 2021 \\
\hline ACCEPTED ON & Wednesday, 08 September 2021 \\
\hline LICENSE & $\begin{array}{l}(\mathrm{cc}) \mathrm{EY} \\
\text { This work is licensed under a Creative Commons Attribution } 4.0 \text { International } \\
\text { License }\end{array}$ \\
\hline JOURNAL & "Banks and Bank Systems" \\
\hline ISSN PRINT & $1816-7403$ \\
\hline ISSN ONLINE & $1991-7074$ \\
\hline PUBLISHER & LLC "Consulting Publishing Company "Business Perspectives" \\
\hline FOUNDER & LLC "Consulting Publishing Company "Business Perspectives" \\
\hline
\end{tabular}

NUMBER OF REFERENCES

46

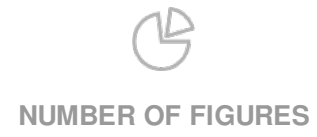

0

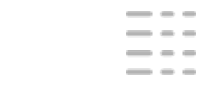

NUMBER OF TABLES

7

(C) The author(s) 2021. This publication is an open access article. 


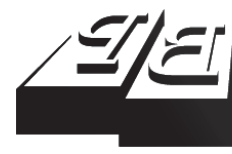

\section{BUSINESS PERSPECTIVES}

9

LLC "CPC "Business Perspectives" Hryhorii Skovoroda lane, 10, Sumy, 40022, Ukraine www.businessperspectives.org
Received on: $31^{\text {st }}$ of May, 2021 Accepted on: $8^{\text {th }}$ of September, 2021 Published on: $15^{\text {th }}$ of September, 2021

(C) Irfan Adhityo Dinutistomo, Arief Wibisono Lubis, 2021

Irfan Adhityo Dinutistomo, B.A., PT Bank Rakyat Indonesia, Jakarta, Indonesia.

Arief Wibisono Lubis, Ph.D., Assistant Professor, Department of Management, Faculty of Economics and Business, Universitas Indonesia, Indonesia. (Corresponding author)

\title{
MSME LENDING AND BANK EFFICIENCY: EVIDENCE FROM INDONESIA
}

\begin{abstract}
Banks prefer to lend to bigger clients for a variety of reasons, including transaction costs and risk considerations. Due to this phenomenon, the Central Bank of Indonesia issued a regulation that requires banks to channel a minimum proportion of their credit portfolio to micro, small, and medium enterprises (MSMEs). Nevertheless, the impact of channeling funds to MSMEs remains a subject of controversy, in part depending on the dimensions and metrics used. This study examines how MSME lending affects the efficiency of banks in Indonesia, a country where MSMEs constitute more than $99 \%$ of business entities. Using a total of 175 panel data observations of banks in Indonesia from 2014-2018, banks' cost efficiency is first estimated using a stochastic frontier approach (SFA). Panel data regression is used to examine the impact of MSME lending on efficiency. The result of this study shows a significant and positive impact of the proportion of MSME lending on bank efficiency, which indicates that requiring banks to channel funds to MSMEs does not only potentially support economic development, but also is beneficial from the business perspective in the Indonesian context.
\end{abstract}

\section{Keywords}

JEL Classification

\section{INTRODUCTION}

Access to financing is one of the main drivers of business sustainability. In this case, banks play a vital role in enabling financial access for small-scale companies, as bank financing is one source of financing for micro, small, and medium enterprises (MSMEs). At the same time, MSMEs play a significant role in the economy due to their ability to generate employment and innovation that will drive economic development (Beck \& Demirgüç-Kunt, 2004).

In Indonesia, most enterprises can be classified as MSMEs. According to the Ministry of Cooperatives and SMEs, as of 2018, there are more than 62 million MSMEs in Indonesia, accounting for $99.99 \%$ of businesses. In terms of their impact on the economy, MSMEs contributed around $60 \%$ of Indonesia's total Gross Domestic Product (GDP) in 2017. In addition, MSMEs have a significant contribution to employment, contributing to $97.02 \%$ of total employment in Indonesia (Ministry of Cooperatives and SMEs, 2018).

Nevertheless, the level of financial inclusion from MSMEs in Indonesia only reaches around $30 \%$ with a distribution of $76.1 \%$ getting access to funding through banks and $23.9 \%$ getting access to funding through non-bank financial institutions (Central Bank of Indonesia, 2015). The government and the Central Bank of Indonesia have taken several important measures to bridge the MSME financing gap. The Central Bank issued Regulation No. 17/12/PBI/2015, which sets a threshold for 
MSME loans that commercial banks must meet. Meanwhile, in 2007, the government of Indonesia issued a portfolio credit scheme named Kredit Usaha Rakyat (People Business Credit/KUR), which is partly guaranteed by institutions appointed by the government (Tambunan, 2017).

Despite these policy initiatives, banks still perceive MSMEs as opaque institutions that have higher asymmetric information and serve a higher credit risk than large enterprises. Previous studies have examined the impact of MSME lending on banks' performance in terms of profitability and risks (see for example, Boadi et al., 2016; Shihadeh et al., 2019). The relationship between MSME lending and efficien$\mathrm{cy}$ is an issue that began to receive attention in the literature, with conflicting results (see among others, Liang et al., 2017; Chih et al., 2018).

Therefore, this study focuses on how MSME loans affect bank efficiency. Following previous studies that examined bank's efficiency, the study also attributes some variables to be employed as control variables into the model, namely profitability, management capability, capital adequacy ratio, and regional banks. In examining the issue, this paper employs stochastic frontier analysis (SFA) to estimate the efficiency scores of Indonesian banks, implementing the maximum likelihood estimation method to estimate the stochastic cost function based on the same model popularized by Battese and Coelli (1995). A random effect regression model is employed to investigate the relationship of MSME lending on the efficiency of Indonesian banks.

\section{LITERATURE REVIEW AND HYPOTHESIS}

\subsection{MSME lending}

MSMEs have various definitions across several countries and agencies, largely depending on their value of income, value of assets, number of employees, and extent to the global economy. While MSMEs generate a significant impact in economic and social perspectives, they tend to have a low information quality in respect to credit market information. This has resulted in MSMEs being a subject of credit rationing, suffering significantly higher credit restrictions compared to large enterprises and hindering their business development (Stiglitz \& Weiss, 1981). This has become an important topic for policymakers in many countries, as they have tried to take various measures to catch up with the imperfection of the credit market mechanism.

From the lenders' perspective, MSMEs are often perceived as having significant limitations in the information and skills required to access external finance (OECD, 2006). Research conducted by the International Finance Corporation (IFC) states that the biggest challenge for banks in providing access to funding to MSMEs is the high credit risk endured by banks, resulting from a lack of qual- ity in information exchanges between the creditors and the lender (IFC, 2019). Thus, MSMEs are being subjected to tighter credit restrictions compared to those applied for large enterprises (Stiglitz \& Weiss, 1981). The absence of a sufficient collateral value leads banks to perceive that MSMEs have higher levels of risk than large enterprises that have fewer problems in meeting the collateral requirement. However, an empirical investigation by Shihadeh et al. (2019) shows a negative association between the proportion of MSME lending and banks' risk level.

Furthermore, in a financial world that includes transaction costs and asymmetric information, small-scale businesses such as MSMEs with smaller loan requests are perceived as having higher transaction costs compared to large enterprises. These factors result in MSMEs facing a higher risk premium because MSMEs are perceived to have lower levels of information disclosure and have fewer guarantees to offer, resulting in banks becoming reluctant in serving MSMEs financing (Beck \& Demirguc-Kunt, 2006). On the other hand, in the context of Ghanaian banks, Boadi et al. (2016) found that MSMEs credit has a positive impact on banks' profitability.

Numerous factors could affect a bank's tendency to finance MSMEs. Boushnak et al. (2018) noted 
that factors such as the owner's character, capacity, capital adequacy, credit score, and the availability of credible information related to company finances are the deciding factors for the bank's decision to provide loans to MSMEs. Another study conducted by Duarte et al. (2016) concluded that personal collateral factors have a positive correlation with lending to MSMEs. Furthermore, the study concluded that younger companies use personal guarantees as a signal of creditworthiness and commitment to access loans and encourage the importance of producing and sharing personal information among lenders to reduce asymmetric information and the need for collateral in the form of assets.

\subsection{Bank efficiency}

Siudek (2008) described efficiency as an indicator that shows the ability of managers and company staff to maintain a level of income and profit growth above the level of an increase in operational costs, while Gordo (2013) mentions that the basic notion of efficiency is the ratio between output and input. Berger and Mester (1997) further defined another means of efficiency: cost efficiency, which measures the level of costs incurred by best-practice banks to produce the same amount of output under the same conditions. Bank efficiency is a significant influence for many variables, mainly the credit interest rate. The efficiency of the bank operations is one of the key variables in determining lending rates, thus influencing a bank's behavior in setting interest rates (Schluter et al., 2012). Pasiouras et al. (2008) also stated that efficiency has a significant influence on a bank's stocks performance.

Numerous studies investigate variables that affect banks' efficiency. Oral and Yolalan (1990) mentioned that there is a relationship between efficiency and profitability. Ǩepková (2015) and Banna et al. (2017) stated that profitability has a negative effect on efficiency. Sari and Saraswati (2017) also stated that a bank's efficiency is influenced by its profitability. Bank efficiency is also influenced by the managerial capability, measured by the cost-income ratio as Pasiouras and Kosmidou (2007) stated that, as the level of a bank's costs grow, the bank's efficiency would plummet. Moreover, Bernauer and Koubi (2002) and Das and Ghosh (2006) showed that there is a positive relationship between the capital adequacy ratio and banks' efficiency, while banks with a higher level of capital adequacy tend to have better credit risk management strategies and lower borrowing costs, which increase their efficiency.

Another factor that influences the level of bank efficiency is the status of regional banks, which could give it an arbitrary advantage in its efficiency level. The arbitrary advantage possessed by a regional bank lies in its ability in the relationship lending factor. This, then, improves the quality of information exchange between creditors and debtors. The existence of these factors makes the efficiency of regional development banks higher (Berger \& Udell, 1995). In the Indonesian context, regional banks are known as bank pembangunan daerah (BPD). BPD is established to provide financing for regional development projects, thus focusing its credit channel on regional-sized projects and local businesses.

\subsection{MSME lending and efficiency}

The earlier subsection demonstrates that there is inconclusive evidence on the overall effect of MSME lending on bank performance. One aspect of bank's performance that is overlooked in the existing literature when examining the effect of MSME lending is efficiency, as research in this area is very limited and yields conflicting results. Among the existing studies, Liang et al. (2017) examine the relationship between MSME lending and bank efficiency and found a negative association. They argue that this is due to the higher asymmetric information among MSMEs compared to the bigger counterparts. In addition, as a response to address the higher asymmetric information, banks are forced to incur additional costs. These further lead to inefficiencies among banks with high proportions of MSMEs lending. On the other hand, Chih et al. (2018) show a positive relationship between MSME lending and bank efficiency. It is not clear how MSME lending correlates with bank efficiency in the context of Indonesian banks. Therefore, the main hypothesis of this study is:

H1: MSME lending significantly affects bank efficiency. 
Following evidence provided by previous studies, return on average assets (ROAA) is included as a proxy of profitability, cost to income ratio (CIR) as a proxy of managerial capability, and capital adequacy ratio (CAR) and Regional Bank as control variables in the model. The summary of the hypothesis for all independent variables is provided in Table 1.

Table 1. Summary of hypothesis and testing type

\begin{tabular}{|c|c|c|}
\hline Variable & $\begin{array}{l}\text { Hypothesis } \\
\text { testing }\end{array}$ & Alternative hypothesis \\
\hline SME & Two-tailed & $B \neq 0$ \\
\hline ROAA & Two-tailed & $B \neq 0$ \\
\hline$C I R$ & One-tailed & $B>0$ \\
\hline CAR & One-tailed & $B>0$ \\
\hline REGBANK & One-tailed & $B>0$ \\
\hline
\end{tabular}

\section{RESEARCH METHODS}

The collected data in this study are mainly sourced from BankFocus, Datastream, financial statements, and reports from Indonesia's Financial Services Authority (Otoritas Jasa Keuangan/OJK). A five-year sampling period from 2014 to 2018 is used, as there is an aim to incorporate the most recent data in the study. After going through the screening process in the form of data cleaning, 35 banks were selected for the sample. Therefore, this study employs a total of 175 observations, constructing a balanced panel data, while the data are mostly nominal accounts, referring to Indonesian Rupiah (IDR) currency. For outliers in this study, the winsorizing process with a threshold of $5 \%$ was conducted.

This study uses stochastic frontier analysis (SFA) to estimate the efficiency of banks. One major advantage in using SFA lies in its ability to be used in estimating panel data, as well as the ability to distinguish between inefficiency term and other stochastic shocks from the error term more accurately to estimate the efficiency scores. In addition, the SFA method also has a relatively better statistical power than the other commonly used method in the topic of efficiency, namely the data envelopment analysis (DEA) (Asmare \& Begashaw, 2018; Huang \& Wang, 2002).
The Battese and Coelli (1995) cost function model was employed to investigate the efficiency scores of each observation using the translog cost function by using three types of inputs and three types of output based on the model used by Christensen et al. (1973) using labor costs, capital costs, and funding costs. The translog cost function should meet the regularity condition of the model that an input share equals the derivative of the log cost function vis-à-vis to the corresponding log input price. The regularity condition by normalizing the total cost and all input costs by the price of labor was applied. The cost function is carried out using the stochastic frontier analysis to estimate the efficiency scores of each observation. Table 2 describes the variable definitions for the cost function, and the cost function is shown by equation 1 .

$\ln \left(\frac{T C}{P_{2 i t}}\right)=\alpha_{0}+\alpha_{1} \ln Y_{1 i t}+\alpha_{2} \ln Y_{2 i t}+$

$+\alpha_{3} \ln Y_{3 i t}+\beta_{1} \ln \left(\frac{P_{1 i t}}{P_{2 i t}}\right)+\beta_{3} \ln \left(\frac{P_{3 i t}}{P_{2 i t}}\right)+$

$+\frac{1}{2} \alpha_{11}\left(\ln Y_{1 i t}\right)^{2}+\frac{1}{2} \alpha_{22}\left(\ln Y_{2 i t}\right)^{2}+$

$+\frac{1}{2} \alpha_{33}\left(\ln Y_{3 i t}\right)^{2}+\alpha_{12} \ln Y_{1 i t} \ln Y_{2 i t}+$

$+\alpha_{13} \ln Y_{1 i t} \ln Y_{3 i t}+\alpha_{23} \ln Y_{2 i t} \ln Y_{3 i t}+$

$+\frac{1}{2} \gamma_{11}\left(\frac{\ln P_{1 i t}}{\ln P_{2 i t}}\right)^{2}+\frac{1}{2} \gamma_{33}\left(\frac{\ln P_{3 i t}}{\ln P_{2 i t}}\right)^{2}+$

$+\gamma_{13} \ln \left(\frac{P_{1 i t}}{P_{2 i t}}\right) \ln \left(\frac{P_{3 i t}}{P_{2 i t}}\right) \rho_{11} \ln Y_{1 i t} \ln \left(\frac{P_{1 i t}}{P_{2 i t}}\right)+$

$+\rho_{13} \ln Y_{1 i t} \ln \left(\frac{P_{3 i t}}{P_{2 i t}}\right)+\rho_{21} \ln Y_{2 i t} \ln \left(\frac{P_{1 i t}}{P_{2 i t}}\right)+$

$+\rho_{23} \ln Y_{2 i t} \ln \left(\frac{P_{3 i t}}{P_{2 i t}}\right)+\rho_{31} \ln Y_{3 i t} \ln \left(\frac{P_{1 i t}}{P_{2 i t}}\right)+$

$+\rho_{33} \ln Y_{3 i t} \ln \left(\frac{P_{3 i t}}{P_{2 i t}}\right)+v_{i t}+u_{i t}$,

where $\ln T C=$ total cost of a bank; $Y_{1 i t}=$ loans of bank $i$ for period $t ; Y_{2 i t}=$ investment of bank $i$ for period $t ; Y_{3 i t}=$ non-interest income of bank $i$ for period $t ; P_{1 i t}^{3 t}=$ price of funding of bank $i$ for period $t ; P_{2 i t}=$ price of labor of bank $i$ for period $t ; P_{3 i t}=$ 
Table 2. Variable definitions of cost function

\begin{tabular}{|c|c|c|}
\hline Variable & Notation & Definition \\
\hline Total cost (IDR 1,000,000) & TC & Labor cost + capital cost + funding cost \\
\hline Fund cost (IDR 1,000,000) & $x_{1}$ & Deposits + borrowing \\
\hline Labor cost (IDR 1,000,000) & $x_{2}$ & Staff expenses \\
\hline Capital cost (IDR 1,000,000) & $x_{3}$ & Net fixed assets \\
\hline Price of funding (\%) & $P_{1}$ & Interest payments / (Deposits + Borrowing) \\
\hline Price of labor (IDR 1,000,000) & $P_{2 \ldots}$ & Staff expenses / Total employees \\
\hline Price of capital (\%) & $P_{3}$ & Operating expense / Net fixed assets \\
\hline Output 1 (IDR 1,000,000) & $Y_{1}$ & Loans $\quad$ L \\
\hline Output 2 (IDR $1,000,000)$ & $Y_{2}$ & Investment (Interest-bearing investments + Non-interest-bearing investment) \\
\hline Output 3 (IDR 1,000,000) & $Y_{3}$ & Non-interest income \\
\hline
\end{tabular}

price of capital of bank $i$ for period $t ; v_{i t}=$ random error of bank $i$ for period $t ; u_{i t}=$ inefficiency term of bank $i$ for period $t$.

After the estimation process, the deviation from the cost frontier can be defined as an error term $\left(e_{i t}\right)$. Then, the error term can be separated between random error $\left(v_{i t}\right)$ and inefficiency term $\left(u_{i t}\right)$, both of which are assumed to be independent of each other and are a function of the factors that cause cost inefficiency. Specifically, it is assumed that the inefficiency term comes from the truncated-normal distribution (Liang et al., 2017). The inefficiency terms can then be estimated to be cost efficiency scores using the estimation model used by Battese and Coelli (1995) in equation 2.

$$
E F F_{i t}=\exp \left(-u_{i t}\right),
$$

where $E F F_{i t}=$ efficiency score of bank $i$ for period $t$; $u_{i t}=$ inefficiency term of bank $i$ for period $t$.

According to the cost function, the resulting cost efficiency score has a range from 0 to 1 . This means that the higher the score, the higher the cost efficiency of a bank (Liang et al., 2017). This score can be interpreted inversely with a bank's inefficiency score. For example, an observation that has an efficiency score of 0.3 means it has an inefficiency score of 0.7 .

The efficiency score is then incorporated to be used as a dependent variable for the regression model to capture the main determinants of bank efficiency in Indonesia. Referring to a previous study conducted by Liang et al. (2017), the main independent variable of this study is the proportion of MSME loans with a proxy of the percentage of loans extended to MSMEs against total loans. This study uses four control variables, namely profitability, manager's capability, capital adequacy ratio, and regional banks. Therefore, the following model is specified:

$$
\begin{aligned}
& E F F_{i t}=\beta_{0}+\beta_{1} S M E_{i t}+\beta_{2} R O A A_{i t}+ \\
& +\beta_{3} C I R_{i t}+\beta_{4} C A R_{i t}+\beta_{5} R E G_{i t}+\varepsilon_{i t},
\end{aligned}
$$

where $E F F_{i t}=$ efficiency score of bank $i$ for period $t$; $S M E_{\mathrm{it}}=$ proportion of bank $i$ for period $t ; R O A A_{i t}=$ return on average assets of bank $i$ for period $t ; C I R_{i t}$ $=$ cost-income ratio of bank $i$ for period $t ; C A R_{i t}=$ capital adequacy ratio of bank $i$ for period $t ; R E G_{i t}=$ the regional bank status of bank $i$ for period $t$.

Table 3 describes the definitions of variables in the

\begin{tabular}{|c|c|c|}
\hline Variable & Notation & Description \\
\hline \multicolumn{3}{|r|}{ Dependent variable } \\
\hline Bank's efficiency & EFF & Bank's efficiency scores calculated using SFA \\
\hline \multicolumn{3}{|r|}{ Independent variable } \\
\hline SME loans & $\mathrm{SME}$ & Ratio of MSME loans to total credit \\
\hline Profitability & ROAA & Ratio of net income to average total asset \\
\hline Manager's capability & $\mathrm{CIR}$ & $\begin{array}{l}\text { Ratio of operating expenses divided by operating income that has been subtracted by net } \\
\text { interest income }\end{array}$ \\
\hline Capital adequacy ratio & CAR & Capital adequacy ratio \\
\hline Regional banks & REGBANK & $\begin{array}{c}\text { Dummy variable with the score of } 1 \text { if a bank is categorized as a regional bank, and } 0 \text { if } \\
\text { others }\end{array}$ \\
\hline
\end{tabular}
efficiency model.

Table 3. Variable definitions and descriptions in the efficiency model 


\section{RESULTS AND DISCUSSION}

Table 4. Results of the stochastic cost frontier model

\begin{tabular}{|c|c|c|c|}
\hline Variable & Coefficient & SE & $P>|z|$ \\
\hline \multicolumn{4}{|c|}{ Frontier } \\
\hline $\operatorname{Ln} Y_{1}$ & 3.4790 & 1.7275 & $0.0440 * *$ \\
\hline $\operatorname{Ln} Y_{2}$ & 0.3946 & 0.5426 & 0.4670 \\
\hline $\operatorname{Ln} Y_{3}$ & 0.7225 & 0.3319 & $0.0290^{* *}$ \\
\hline $\operatorname{Ln} P_{1} P_{2}$ & -1.4947 & 0.4927 & $0.0020^{* * *}$ \\
\hline $\operatorname{Ln} P_{3} P_{2}$ & 1.6739 & 0.3620 & $0.0000 * * *$ \\
\hline $1 / 2 \operatorname{Ln}\left(Y_{1}\right)^{2}$ & -27.0976 & 18.4380 & 0.1420 \\
\hline $1 / 2 \operatorname{Ln}\left(Y_{2}\right)^{2}$ & (omitted) & (omitted) & (omitted) \\
\hline $1 / 2 \operatorname{Ln}\left(Y_{3}\right)^{2}$ & 14.9418 & 5.7325 & $0.0090 * * *$ \\
\hline $\operatorname{LnY}{ }_{1} \operatorname{Ln} Y_{2}$ & -0.02565 & 0.0192 & 0.1830 \\
\hline $\operatorname{Ln} Y_{1} \operatorname{Ln} Y_{3}$ & -5.2788 & 3.3214 & 0.1120 \\
\hline $\operatorname{LnY}{ }_{2} \operatorname{Ln} Y_{3}$ & -0.6763 & 3.2163 & 0.8330 \\
\hline $1 / 2 \operatorname{Ln}\left(P_{1} / P_{2}\right)^{2}$ & -0.2386 & 0.0560 & $0.0000 * * *$ \\
\hline $1 / 2 \operatorname{Ln}\left(P_{3} / P_{2}\right)^{2}$ & 0.2006 & 0.0553 & 0.1020 \\
\hline $\begin{array}{l}\operatorname{Ln}\left(P_{1} /\right. \\
\left.P_{2}\right) \cdot \operatorname{Ln}\left(P_{3} / P_{2}\right)\end{array}$ & 0.0521 & 0.0318 & 0.7080 \\
\hline $\operatorname{Ln} Y \cdot \operatorname{Ln}\left(P_{1} / P_{2}\right)$ & -0.0088 & 0.0236 & 0.8670 \\
\hline $\operatorname{Ln} Y_{1} \cdot \operatorname{Ln}\left(P_{3} / P_{2}\right)$ & -0.0060 & 0.0364 & 0.4350 \\
\hline $\operatorname{Ln} Y_{2} \cdot \operatorname{Ln}\left(P_{1} / P_{2}\right)$ & 0.0339 & 0.0435 & 0.2270 \\
\hline $\operatorname{LnY} \cdot \operatorname{Ln}\left(P_{3} / P_{2}\right)$ & (omitted) & (omitted) & (omitted) \\
\hline $\operatorname{Ln} Y_{3} \cdot \operatorname{Ln}\left(P_{1} / P_{2}\right)$ & 0.0494 & 0.0229 & $0.0310^{* *}$ \\
\hline $\operatorname{Ln} Y_{3} \cdot \operatorname{Ln}\left(P_{3} / P_{2}\right)$ & 0.0016 & 0.0262 & 0.9500 \\
\hline Cons & 26.3715 & 27.6375 & 0.3400 \\
\hline \multicolumn{4}{|c|}{$\mathrm{Mu}$} \\
\hline Cons & -6.8326 & 9.2293 & 0.4590 \\
\hline \multicolumn{4}{|c|}{ Usigma } \\
\hline Cons & 0.6671 & 1.2450 & 0.5920 \\
\hline \multicolumn{4}{|c|}{ Vsigma } \\
\hline Cons & -3.5605 & 0.2791 & 0.0000 \\
\hline Sigma u & 1.395 & 0.8690 & 0.1080 \\
\hline Sigma v & 0.1685 & 0.0235 & 0.0000 \\
\hline Lambda & 8.2803 & 0.8720 & 0.0000 \\
\hline $\begin{array}{l}\text { Log likelihood } \\
\text { function }\end{array}$ & \multicolumn{3}{|c|}{-28.966} \\
\hline Prob >chi2 & \multicolumn{3}{|c|}{0.00000} \\
\hline
\end{tabular}

Note: $* * *, * *$, and $*$ represent the significance levels at $1 \%$, $5 \%$, and $10 \%$, respectively.

This study uses STATA 14 to carry out the estimation based on the maximum likelihood method. Table 4 shows the result of a stochastic frontier estimation. It can be seen that there are two variables that are not included in the estimation process due to multicollinearity problems. Based on the Prob > chi 2 value it can be concluded that there is a significance level of 5\%, and, therefore there is sufficient evidence to conclude that the parameters used in the model have a significant effect. There is a total of seven variables that can be called significant at different significance levels, namely $5 \%$ and $1 \%$.
The sample consists of all commercial banks in the Indonesian banking system. After the screening process, 35 banks are selected as a sample of the study with 27 commercial banks and eight regional banks. Table 5 shows the descriptive statistics of the variables after the winsorizing process, while Table 6 shows the correlation between the efficiency scores and CIR. Descriptive statistics shows that EFF has an average value of 0.7919 on a scale of 0 to 1 . The average value means that the observed sample has an average efficiency level of 0.7919 , indicating the 35 banks observed during the observation period have relatively high levels of cost-efficiency. The correlation of efficiency scores calculated was tested using SFA method with $C I R$, as a variable that is widely used by banks to measure operational efficiency. Based on the pairwise correlation in Table 5 , it is concluded that there is no strong correlation between the two, indicating that there is a difference in the measurement of efficiency scores and CIR.

Table 5. Descriptive statistics of the efficiency model

\begin{tabular}{|c|c|c|c|c|c|c|}
\hline Variable & Mean & Median & Std. dev & Min & Max & Obs. \\
\hline EFF & 0.7919 & 0.8423 & 0.1440 & 0.1996 & 0.9595 & 175 \\
\hline SME & 0.1402 & 0.1228 & 0.1113 & 0 & 0.4636 & 175 \\
\hline ROAA & 0.0119 & 0.0130 & 0.0140 & -0.0372 & 0.0328 & 175 \\
\hline CIR & 0.5542 & 0.5429 & 0.1709 & 0.2276 & 1.0946 & 175 \\
\hline CAR & 0.2161 & 0.1944 & 0.1048 & 0.1348 & 0.7777 & 175 \\
\hline REGBANK & 0.2571 & 0 & 0.4383 & 0 & 1 & 175 \\
\hline
\end{tabular}

Table 6. Pairwise correlation of EFF and CIR

\begin{tabular}{l|c|c}
\hline & EFF & CIR \\
\hline EFF & 1.0000 & \\
CIR & 0.0990 & 1.0000 \\
\hline
\end{tabular}

Based on the Hausman test, random effect regression was used. In addition, the use of the generalized least squares (GLS) method in the random effect estimation assumed that there are no heteroscedasticity and autocorrelation problems (Brooks, 2014). As Table 6 shows, no multicollinearity problem is indicated in the model. Table 7 presents the estimation results of the efficiency model. The regression result shows that there is a significant positive relationship between the SME lending proportion and cost efficiency of a bank, meaning that an increase 
in the SME lending ratio would increase the efficiency of a bank. The empirical result of this study supports Chih et al. (2008). Referring to the previous studies, the perception of the negative effect of MSME to banks' efficiency lies in the existence of asymmetric information. This will then lead to the risk of moral hazards, as well as transaction and monitoring costs borne by the bank as a creditor (Beck \& DemirgucKunt, 2006).

Table 7. Efficiency model result

\begin{tabular}{l|c|c|c}
\hline Variable & Coefficient & SE & P>|z| \\
\hline SME & 0.3760 & 0.1344 & $0.0050^{* * *}$ \\
ROAA & -1.9591 & 0.8438 & $0.0200^{* *}$ \\
\hline CIR & 0.0534 & 0.0920 & 0.2805 \\
CAR & 0.2748 & 0.1523 & $0.0365^{* *}$ \\
REGBANK & 0.0262 & 0.0504 & 0.3015 \\
Cons & 0.4838 & 0.0714 & $0.0000^{* * *}$ \\
N & & 175 & \\
\hdashline$R^{2}$ & & 0.1113 & \\
\hdashline Prob > chi2 & & 0.0011 & \\
\hline
\end{tabular}

Note: $* * *, * *$, and $*$ represent the significance level at $1 \%$, $5 \%$, and $10 \%$, respectively.

However, the creation of efficiency or inefficiency resulting from lending to MSME consumers depends on many factors. The problem of asymmetric information can be solved by several factors, one of which is relationship lending. Through several dimensions, relationship lending would provide a higher quality of information to banks. One dimension of the relationship lending is duration, as the longevity of the relationship between the debtor and creditor will improve the quality of information exchanges that occur, obtaining sufficient information by observing the history of financial transactions that occur with a particular debtor, which, in turn, will reduce asymmetric information (Rajan \& Petersen, 1994). Another dimension of relationship lending is transactions that occur on other products. The debtor may probably become a bank's client in several other products, such as short-term deposits, deposits, and other products. This would increase the level of information quality about the debtor, for example, information about cash flow in the debtor's account. Hence, banks would be able to save costs to overcome the asymmetric information for one particular debtor, resulting in a decrease in inefficiency (Berger et al., 2001; Rajan \& Petersen, 1994).
From an external perspective, the regulator's active role in encouraging the growth of loans to the MSME sector has helped banks in channeling loans to the MSME sector. The existence of a bureau responsible for storing integrated information related to prospective debtors would ease the screening process, increasing the information quality and helping to avoid moral hazard (Ramcharran, 2017). In the Indonesian context, OJK as a regulator has formed a similar body named Sistem Layanan Informasi Keuangan (SLIK). The presence of SLIK then helps the Indonesian banking industry to minimize asymmetric information when conducting credit analysis, which, in turn, will increase efficiency in lending to MSMEs. The existence of a credit guarantee scheme would transfer some of the lending risks to a third party, thus reducing the risk endured by banks. The scheme plays a crucial role in improving banks' efficiency. The existence of a policy that reduces a credit risk significantly allows banks to endure a lower level of risk while achieving the same level of output (Wardhono et al., 2019).

A significant negative relationship is found between profitability and bank efficiency. The result of the study support previous studies conducted by Řepková (2015) and Banna et al. (2017). Higher profitability does not necessarily reflect a higher efficiency. In some cases, high profitability would give an insight into an organization's preference toward risky projects, which offers a higher return. This behavior could result in an inefficiency resulted from the efforts made by a bank's operations in pursuit of higher profitability, reflected in a higher expense resulting from the transaction and monitoring costs that serve as a consequence of the bank's behavior (Zouhaier, 2015). High margins also symbolize higher credit risks and would serve as a cause for banks' inefficiencies (Niţoi \& Spulbar, 2015).

According to the result of this study, there was no significant relationship between the cost-income ratio and the bank's efficiency. Burger and Moormann (2008) argued that the cost-income ratio cannot be the right picture to describe the efficiency and productivity of banks due to market conditions, which have a great influence on the determinants of the cost-income ratio. 
A significant positive effect is found between the capital adequacy ratio and bank inefficiency. The results support previous studies conducted by Pasiouras and Kosmidou (2007) and Liang et al. (2017). In the case of moral hazard, banks with higher capital adequacy would steer clear of any moral hazard activities because the potential losses incurred would be charged upon the bank's front. It serves as an incentive for banks to avoid any moral hazard activities, thus, improving bank's efficiency. Das and Ghosh (2006) stated that banks with high levels of capital adequacy are perceived as relatively safe and would contribute to a reduction of borrowing costs. A decrease in the cost of borrowing would increase a bank's efficiency (Bernauer \& Koubi, 2002).

According to the result of this study, no significant influence of regional banks on bank efficiency was found. Berger and Udell (1995) stated that the existence of relationship lending would increase the level of regional banks' efficiency because of the existence of a financial relationship that makes regional banks have a better ability to obtain higher quality information from their debtors. Even so, this factor largely depends on the bank's ability to administer relationship lending, as no significant difference was found in the efficiency level between commercial banks and regional banks.

\section{CONCLUSION}

The purpose of this study is to investigate the impact of MSME lending on the efficiency of banks as there is debate on the impact of MSME lending on bank performance in the context of Indonesian banks. This study also includes profitability, managerial capability, CAR, and regional banks as control variables. As a result, the higher the MSME lending ratio, the higher the efficiency of banks. Therefore, MSME lending by banks does not only play a key role in supporting economic development, as more than $99 \%$ of businesses in Indonesia can be classified as MSMEs, but also is beneficial for banks' performance in terms of efficiency. Among the control variables, profitability and CAR have statistically significant relationships with efficiency.

One possible explanation on the positive relationship between MSME lending and bank efficiency is the existence of relationship lending, a bureau that integrates debtors' information, and a credit guarantee scheme in the Indonesian banking system, which aims to support banks in providing credits to MSMEs. The result also suggests that government policies to ease MSME loans will play a significant role in making a bank choose to channel MSME loans. Policies to increase SME lending in the form of incentives, risk-reduction, and efforts to minimize asymmetric information have proven to be critical to improving a bank's efficiency, increasing banks' preference to disburse loans to the MSME sector. From the bank's point of view, asymmetric information problems can be solved by applying the relationship lending principle in various dimensions.

It should be noted that this study has some limitations. The most crucial of these is the limited accessibility to the required data. The SFA method is very sensitive to the lack of data, which significantly reduces the quality of the estimation. As a result, the sample size has been reduced. In addition, other external factors affect the result of this study. The tendency of banks to disburse MSME loans largely depends on a bank's business strategy. Banks that choose the MSME sector as their primary target will tend to have a higher proportion of MSME loans. However, it was not possible to define banks that have chosen the MSME sector as their primary target due to its arbitrary status as it is prone to bias.

Another crucial limitation of the study is the estimation of the efficiency model. The dependent variable estimated using the SFA method is performed on a quadratic cost function model. The efficiency score was then used as a dependent variable for the efficiency model in the form of a linear regression model, establishing a risk that the estimated results obtained would be less accurate. There is a possibility that there are other estimation techniques that can provide a more robust explanation for the model, such as a quadratic regression model. 


\section{AUTHOR CONTRIBUTIONS}

Conceptualization: Irfan Adhityo Dinutistomo, Arief Wibisono Lubis.

Data curation: Irfan Adhityo Dinutistomo.

Formal analysis: Irfan Adhityo Dinutistomo.

Fund acquisition: Arief Wibisono Lubis.

Investigation: Irfan Adhityo Dinutistomo, Arief Wibisono Lubis.

Methodology: Irfan Adhityo Dinutistomo, Arief Wibisono Lubis.

Project administration: Irfan Adhityo Dinutistomo, Arief Wibisono Lubis.

Resources: Irfan Adhityo Dinutistomo, Arief Wibisono Lubis.

Software: Irfan Adhityo Dinutistomo.

Supervision: Arief Wibisono Lubis.

Validation: Irfan Adhityo Dinutistomo, Arief Wibisono Lubis.

Visualization: Irfan Adhityo Dinutistomo.

Writing - original draft: Irfan Adhityo Dinutistomo.

Writing - review \& editing: Irfan Adhityo Dinutistomo, Arief Wibisono Lubis.

\section{ACKNOWLEDGMENT}

The research was also made possible with the support of PUTI Grant by Universitas Indonesia No. NKB2036/UN2.RST/HKP.05.00/2020.

\section{REFERENCES}

1. Ang, J. S. (1991). Small business uniqueness and the theory of financial management. Journal of Small Business Finance, 1(1), 1-13. Retrieved from https://digitalcommons.pepperdine.edu/jef/vol1/ iss $1 / 2$

2. Asmare, E., \& Begashaw, A. (2018). Review on parametric and nonparametric methods of efficiency analysis. Biostatistics and Bioinformatics, 2(2), 1-7. http://dx.doi.org/10.31031/ aaoa.2018.02.000534

3. Banna, H., Ahmad, R., \& Koh, E. H. Y. (2017). Determinants of commercial banks' efficiency in Bangladesh: Does crisis matter? The Journal of Asian Finance, Economics and Business, 4(3), 19-26. https://doi.org/10.13106/ jafeb.2017.vol4.no3.19

4. Battese, G. E., \& Coelli, T. J. (1995). A model for technical inefficiency effects in a stochastic frontier production function for panel data. Empirical Economics, 20, 325-332. Retrieved from https:// link.springer.com/article/10.1007/ BF01205442
5. Beck, T., \& Demirgüç-Kunt, A. (2004). SMEs, growth, and poverty. Do pro-SME policies work? (Note No. 264). Washington: World Bank. Retrieved from http://hdl. handle.net/10986/11278

6. Beck, T., \& Demirgüç-Kunt, A. (2006). Small and mediumsize enterprises: Access to finance as a growth constraint. Journal of Banking and Finance, 30(11), 2931-2943. http:// dx.doi.org/10.1016/j.jbankfin.2006.05.009

7. Berger, A. N., \& Mester, L. J. (1997). Inside the black box: What explains differences in the efficiencies of financial institutions? Journal of Banking and Finance, 21(7), 895-947. https://doi.org/10.1016/S03784266(97)00010-1

8. Berger, A. N., \& Udell, G. F. (1995). Relationship lending and lines of credit in small firm finance. The Journal of Business, 68(3), 351-381. Retrieved from https://www.jstor. org/stable/2353332

9. Berger, A. N., Klapper, L. F., \& Udell, G. F. (2001). The ability of banks to lend to informationally opaque small businesses. Journal of Banking and Finance, 25(12), 2127-2167. Retrieved from https:// ideas.repec.org/a/eee/jbfina/v25y2001i12p2127-2167.html

10. Bernauer, T., \& Koubi, V. (2002). Regulating bank capital: Does market discipline facilitate or replace capital adequacy rules? (Working Paper). Zurich: Center for International Studies, ETH Zurich.

11. Boadi, E.K., Li, Y., \& Lartey, V.C. (2016). Role of bank specific, macroeconomic and risk determinants of banks profitability: Empirical evidence from Ghana's rural banking industry. International Journal of Economics and Financial, 6(2), 813-823. Retrieved from https:// www.econjournals.com/index. php/ijefi/article/view/1835/pdf

12. Boushnak, E., Rageb, M. A., Ragab, A. A., \& Sakr, A. M. (2018). Factors influencing credit decision for lending SMEs: A case study on National Bank of Egypt. Open Access Library Journal, 5, e4996. 
https://dx.doi.org/10.4236/oalib.1104996

13. Brooks, C. (2014). Introductory Econometrics for Finance (3rd ed.). Cambridge: Cambridge University Press.

14. Burger, A., \& Moormann, J. (2008). Productivity in banks: Myths \& truths of the cost income ratio. Banks and Bank Systems, 3(4), 85-94. Retrieved from https://www.businessperspectives.org/images/pdf/applications/ publishing/templates/article/assets/2374/BBS_en_2008_4_Burger. pdf

15. Central Bank of Indonesia and LPPI. (2015). Profil Bisnis Usaha Mikro, Kecil, dan Menengah. Bank Indonesia, Jakarta. (In Indonesian). Retrieved from http://elistia.weblog.esaunggul.ac.id/wp-content/uploads/ sites/1877/2017/09/Profil-BisnisUMKM-bab-1-dan-2.pdf

16. Central Bank of Indonesia. (2012). Commercial Banks Lending or Financing for Micro, Small and Medium Enterprises Development (Regulation No. 14/22/PBI/2012). (In Indonesian). Retrieved from https://www.ojk.go.id/id/kanal/ perbankan/regulasi/peraturanbank-indonesia/Documents/38. pdf

17. Central Bank of Indonesia. (2015). Revision of Commercial Banks Lending or Financing for Micro, Small and Medium Enterprises Development (Regulation No. 17/12/PBI/2015). (In Indonesian). Retrieved from https://peraturan. bpk.go.id/Home/Details/135527/ peraturan-bi-no-1712pbi2015tahun-2015

18. Chih, S. H., Liang, L, \& Huang, B. (2018). The study on the relationship between bank M\&A, SME lending, credit guarantee, and bank efficiency. Romanian Journal of Economic Forecasting, 21(2), 95-117. Retrieved from https://ipe.ro/rjef/rjef2_18/ rjef2_2018p95-117.pdf

19. Christensen, L. R., Jorgenson, D. W., \& Lau, L. J. (1973). Transcendental logarithmic production frontiers. The Review of Economics and
Statistics, 55(1), 28-45. https://doi. org/10.2307/1927992

20. Das, A., \& Ghosh, S. (2006). Financial deregulation and efficiency: An empirical analysis of Indian banks during the post reform period. Review of Financial Economics, 15(3), 193-221. https:// doi.org/10.1016/j.rfe.2005.06.002

21. Duarte, F. D., Ana, P. M. G., \& Jose, P. E. (2016). Collateral-based in SME lending: The role of business collateral and personal collateral in less-developed countries. Research in International Business and Finance, 39(A), 406-422. Retrieved from https://daneshyari. com/article/preview/6481253.pdf

22. Gordo, G. M. (2013). Estimating Philippine bank efficiencies using frontier analysis. Philippine Management Review, 20, 17-36. Retrieved from https://pmr.upd. edu.ph/index.php/pmr/article/ view/311/310

23. Government of Republic of Indonesia. (2008). Micro, Small, and Medium Enterprises. Law of The Republic of Indonesia No. 20 of 2008. Retrieved from https:// peraturan.go.id/common/dokumen/terjemah/2020/LEMBARAN\%20LEPAS\%20BATANG\%20 TUBUH\%20UU\%20NO\%20 20\%20TH\%202008.pdf

24. Gujarati, D. N., \& Porter, D. C. (2009). Basic Econometric (5th ed.). New York: McGraw-Hill.

25. Huang, T. H., \& Wang, M. H. (2002). Comparison of economic efficiency estimation methods: Parametric and non-parametric techniques. Manchester School, 70(5), 682-709. https://doi. org/10.1111/1467-9957.00320

26. Indonesia Ministry of Cooperatives and SMEs. (2018). Laporan Perkembangan Data Usaha Mikro, Kecil, Menengah (UMKM) dan Usaha Besar (UB) Tahun 2016-2017. (In Indonesian). Retrieved from https://www. kemenkopukm.go.id/uploads/ laporan/1584006686_UMKM\%20 2016-2017\%20rev.pdf

27. International Finance Corporation (IFC). (2019). Banking on SMEs: Trends and Challenges. Retrieved from https://www.ifc.org/wps/ wcm/connect/dd06b824-c38b4933-9108-0c834f182fee/IFC +on+Banking+SMEs+Public ation+June+2019.pdf?MOD$=\mathrm{AJPERES} \& \mathrm{CVID}=\mathrm{mSdrGt} \mathrm{A}$

28. Liang, L. W., Huang, B. Y., Liao, C. F., \& Gao, Y. T. (2017). The impact of SMEs' lending and credit guarantee on bank efficiency in South Korea. Review of Development Finance, 7(2), 134-141. Retrieved from https:// journals.co.za/doi/abs/10.1016/j. rdf.2017.04.003

29. Niţoi, M., \& Spulbar, C. (2015). An examination of banks' cost efficiency in Central and Eastern Europe, Procedia Economics and Finance, 22, 544-551. Retrieved from https://core.ac.uk/download/ pdf/82733229.pdf

30. OECD. (2005). OECD SME and Entrepreneurship Outlook 2005. Paris: OECD Publishing. Retrieved from https://www. oecd-ilibrary.org/industryand-services/oecd-sme-andentrepreneurship-outlook2005-edition 9789264009257-en

31. OECD. (2006). The SME financing gap: theory and evidence. Financial Market Trends, 2, 89-97. https://doi.org/10.1787/fmtv2006-art11-en

32. Oral, M., \& Yolalan, R. (1990). An empirical study on measuring operating efficiency and profitability of bank branches. European Journal of Operational Research, 46(3), 282-29. https://doi.org/10.1016/03772217(90)90002-S

33. Pasiouras, F., \& Kosmidou, K. (2007). Factors influencing the profitability of domestic and foreign commercial banks in the European Union. Research in International Business and Finance, 21(2), 222-237. https://doi. org/10.1016/j.ribaf.2006.03.007

34. Pasiouras, F., Liadaki, A., \& Zopounidis, C. (2008). Bank efficiency and share performance: Evidence from Greece. Applied Financial Economics, 18(14), 1121-1130. https://doi. org/10.1080/09603100701564346 
35. Rajan, R. G., \& Petersen, M. A. (1994). The benefits of lending relationships: Evidence from small business data. The Journal of Finance, 49(1), 3-37. https:// doi.org/10.1111/j.1540-6261.1994 tb04418.x

36. Ramcharran, H. (2017). Financing small and mediumsized enterprises in Thailand: The importance of bank loans and financing diversification. The Journal of Entrepreneurial Finance, 19(2). Retrieved from https://www.econstor.eu/bitstre am/10419/197543/1/1663017093. pdf

37. ̌epková, I. (2015). Banking efficiency determinants in the Czech banking sector. Procedia Economics and Finance, 23, 191196. https://doi.org/10.1016/ S2212-5671(15)00367-6

38. Sari, P. Z., \& Saraswati, E. (2017). The determinant of banking efficiency in Indonesia: DEA approach. Journal of Accounting and Business Education, 1(2), 208229. Retrieved from http://journal. um.ac.id/index.php/jabe/article/ view/8489

39. Schlüter, T., Busch, R., Hartmann-Wendels, T., \& Sievers,
S. (2012). Determinants of the interest rate pass-through of banks: Evidence from German loan products (Discussion Papers No. 26/2012). Deutsche Bundesbank. Retrieved from https:// www.bundesbank.de/resource/ blob/703690/d6e3293556542409a$811 \mathrm{~b} 51 \mathrm{a} 62 \mathrm{c} 019 \mathrm{a} 8 / \mathrm{mL} / 2012-10$ 08-dkp-26-data.pdf

40. Shihadeh, F. H., Gamage, S. K. N., \& Hannoon, A. (2019). The causal relationship between SME sustainability and banks' risk. Economic Research-Ekonomska Istraživanja, 32(1), 2743-2760. https://doi.org/10.1080/133167 7X.2019.1655465

41. Siudek, T. (2008). Theoretical foundations of banks efficiency and empirical evidence from Poland. Socialiniai Tyrimai, 13(3), 150-158.

42. Stiglitz, J., \& Weiss, A. (1981). Credit rationing in markets with imperfect information. American Economic Review, 71(3), 393-410. Retrieved from https://www.jstor. org/stable/1802787

43. Tambunan, T. (2017). The performance of Indonesia's public credit guarantee scheme for MSMEs: A regional comparative perspective. Journal of Southeast Asian Economics, 35(2), 31932. Retrieved from https:// www.semanticscholar.org/ paper/The-Performance-ofIndonesia\%E2\%80\%99s-PublicCredit-Scheme-Tambunan/6a10f 460778c5c099f9896eb2f82ffe 974 $3 \mathrm{~b} 7 \mathrm{c} 05$

44. Wardhono, A., Modjo, M. I., \& Utami, E. W. (2019). Role of credit guarantee for financing MSMEs: Evidence from rural and urban areas in Indonesia (ADBI Working Paper Series No. 967). Asian Development Bank Institute. Retrieved from https://www.adb. org/sites/default/files/publication/506966/adbi-wp967.pdf

45. World Bank. (2008). Finance for all? Policies and Pitfalls in Expanding Access. World Bank Policy Research Report. Retrieved from http://hdl.handle net/10986/6905

46. Zouhaier, H. (2015). Financial efficiency, competitiveness and profitability of Islamic banks. Journal of Applied Economic Sciences, 10(4), 593606. Retrieved from https:// www.ceeol.com/search/articledetail id $=537272$ 